\title{
WOOD CHIP EXPORTS AND THE CHALLENGES FACED BY PRIVATE PULPWOOD FARMERS IN SOUTHERN KWAZULU-NATAL
}

\author{
Lenny Naidoo" \\ NCT Durban Wood Chips (Pty) Ltd \\ lenny@nctchips.co.za
}

\author{
Mihalis Chasomeris+ \\ University of KwaZulu-Natal \\ chasomerisml@ukzn.ac.za
}

May 2012

\begin{abstract}
The South African forestry industry contributes to the economic growth of the country by the planting of trees and the processing of these trees for the export market. The purpose of this study is to examine the trends in wood chip exports from the Port of Durban and to examine the stability and growth of private pulpwood production in Southern KwaZulu-Natal. The methodology used in this study includes questionnaires distributed to timber farmers and semi-structured interviews with respondents in forestry. The findings show that wood chip exports from Durban have increased between 2006 and 2011. Dominant challenges faced by the farmers were land reform, transportation costs and municipal rates. Land claims, road infrastructure, cash flow and variation in the demand for timber were the most challenging factors affecting private timber production.
\end{abstract}

Keywords

Wood Chip Exports, Pulpwood Farmers, Port of Durban, Wood and Paper Production.

\#Mr Lenny Naidoo is the Financial Manager at NCT Durban Wood Chips (Pty) Ltd and an MBA graduate of the Graduate School of Business and Leadership, University of KwaZulu Natal, South Africa.

+Dr Mihalis Chasomeris is a Maritime Economist and the Academic Leader of Teaching and Learning at the Graduate School of Business and Leadership, University of KwaZuluNatal, South Africa. 


\section{INTRODUCTION}

The South African forestry industry has contributed to the economic growth of the country by the planting of trees and the processing of these trees for the export market. With the increased demand for wood chips, the wood chip industry is concerned that the plantation resource that is currently available may not be adequate to fulfil the production required for future wood chip export (Joemat-Pettersson, 2009; Timberwatch, 2009).

The purpose of this study is to examine the trends in wood chip exports from the Port of Durban and the stability and growth of private pulpwood production in Southern KwaZulu-Natal. The forestry pulp and paper sector and its related downstream manufacturing enterprises is an important part of the KwaZulu-Natal economy. Eucalyptus and wattle timber are used to manufacture pulp and are exported in the form of wood chips. The Durban wood chipping facility is aimed at the export of wood chips from Durban to pulp and paper manufacturers in Japan.

The methodology used in this study included questionnaires and semi-structured interviews that were held with the respondents involved in the forestry industry. A questionnaire was sent electronically to 119 participants, who constitute the total population of timber farmers that supply NCT Durban Wood Chips. A total of 33 respondents completed the questionnaire resulting in a $27.73 \%$ response rate. Three key personnel, with a strong forestry background, belonging to NCT Forestry Co-operative Limited were selected as participants for the qualitative aspect of the study.

The paper is structured as follows. Section 2 reviews the literature on timber shortages in South Africa, the current export of wood chips and the challenges faced by private timber farmers. Section 3 discusses the research methodology used and collection of the data. Section 4 discusses the results and findings from the questionnaire and interviews. Section 5 concludes the study.

\section{LITERATURE REVIEW}

Key findings of the literature reviewed are discussed under the following headings.

\subsection{Timber shortage in the country}

According to During and Whales (2009), five regions contain high concentrations of timber plantations: Southern KwaZulu-Natal, Midlands, Northern KwaZulu-Natal, Zululand and Maputaland. Some $38.50 \%$ of the land in the province of KwaZulu-Natal (half a million hectares) is allocated to timber plantations. During and Whales (2009) also report that $70 \%$ of the land allocated to timber plantations is devoted to hardwoods of which eucalyptus and wattle are the major species. $30 \%$ of the land is devoted to pine. In South Africa pine is the only softwood that is grown in large quantities.

According to Taylor (2009), land reform, access to funding and skills shortage are the challenges and constraints that have affected the forestry sector and prevented this sector from realising its full potential as well as its contribution to sustainable development. Thompson (2008) believes that the planting of new areas is hampered by the timber permit restrictions. In 2006 the industry planted just under 3000 new hectares as compared with the 1980s when approximately 20000 hectares were planted. Timber plantations are being converted for 
alternative land use at the rate of approximately 3000 ha per annum, leading to minimal growth rate in the net planted area (Thompson, 2008). Joemat-Pettersson (2009) reported that there have been several studies over the last few years that have confirmed that the country is now beginning to experience a shortage of timber and this can be expected to affect the government's intentions to achieve a 6\% economic growth rate. The Forestry Roadmap 2030 (2009) reported that the effects of a shortage of timber is already evident in some parts of the country. This is having an unfavourable effect on the sustainability of pulp and paper operations and on local sawmilling and poses a threat to employment opportunities and local economies. It is expected that South Africa will not be able to meet its domestic demand for timber from the existing growing stock in the future. The outcome of this will affect the national economy through increased prices and lack of timber products to meet domestic demand.

According to Joemat-Pettersson (2009), the mean estimated long-term sustainable supply scenario of timber from 2005 to 2034 is 19 million tonnes, while the estimated sustainable demand is 25 million tonnes. This represents a $23.6 \%$ deficit, which cannot be met by local supply of timber. The consequence of this shortage would be to reduce timber exports or to require the importation of the shortfall. There are risks involved with timber imports that include the introduction of pests and diseases, which may threaten the local forestry industry (JoematPettersson, 2009).

\subsection{The export trends of wood chips from Durban}

During and Whales (2009) found that the export market for pulp and paper is strong. The forestry pulp and paper sector and its related downstream manufacturing enterprises is an important part of the KwaZulu-Natal economy. The forest product export sector comprises solid wood $(23.3 \%)$, paper $(45.2 \%)$, and pulp (28.9\%) (During \& Whales, 2009). The global economic downturn had a significant effect on the forestry and paper industry. Wood sales in South Africa of 14.2 million tonnes in 2009 were down by 2.3 million tonnes (or 14\%) from 2008. Even though local demand is diminishing, the export market for pulp and paper from South Africa remains strong and this sector contributed about R2 billion to the nation's balance of payments in 2009 (During \& Whales, 2009).

According to Chamberlain, Essop, Hougaard, Malherbe and Walker (2005), the export of wood chips is a contentious market in South Africa. The wood chip market has achieved higher prices for plantation owners by successfully breaking the pricing monopoly of the large pulp plants in South Africa (Chamberlain et al., 2005). The wood chip market's survival has been based on a single international buyer, namely Japan. An efficient shipping transport system has been created by Japan, which enables them to transport wood chips cost-effectively over large distances. Japan sourced wood chips from various countries and is the largest importer of wood chips internationally (Chamberlain et al., 2005).

Eucalyptus and wattle timber are used to manufacture pulp and are exported in the form of wood chips. According to the KwaZulu-Natal Department of Transport (2008), South Africa has four wood chip export facilities, one at the Port of Durban and three in Richards Bay. According to the National Ports Authority export statistics for 2006/07, 3728948 tonnes of wood chips were exported through the Port of Richards Bay. The Durban wood chipping facility is aimed at the export of wood chips from Durban to pulp and paper manufacturers in Japan. Kime (2009) reported that during the year 2009 the South African Rand (ZAR) strengthened against the US Dollar (\$) by $25 \%$. Consequently, the Japanese wood chip prices decreased by $14 \%$ and the volume of wood chips exported to Japan was reduced by $40 \%$ (Kime, 2009). 
The wood chip export facility in Durban exported the first wood chips in February 2005 (Keyser, 2011). This facility has experienced steady growth and, in the 2009 financial year, exported a total of 575585 tonnes of wood chips. In 2010, due to the recession, the facility exported 431 876 tonnes. According to Kime (2010), the Japanese pulp and paper industry shrunk by $20 \%$ in 2010 compared with 2009 due to the world recession. The recession in 2010 and the high stocks of wood chips in Japan necessitated the rationing of orders by NCT to its members to cater for the reduction in wood chips sales (Kime, 2010). This, together with the need to reduce the high wood chip stocks in Japan, resulted in ship sales volumes being reduced in 2010 by approximately $30 \%$ (Kime, 2010). In the financial year ending 2011 the export from the facility was 508698 tonnes. The chairman of NCT Durban Wood Chips reported that the wood chipping mill reached a milestone in July 2011 when the mill exported its three millionth tonne of wood chips to Japan during its seventh year of operation (Keyser, 2011).

Wattle and eucalyptus (gum tree) wood chips are exported from the Durban facility. In 2006, the eucalyptus exports were $80 \%$ and wattle was $20 \%$ of the total export (see FIGURE 1). Over the years the export of wattle has increased and in 2009 the total wattle exported was $41.50 \%$. In 2010 wattle exports were $43.40 \%$ and $201142.50 \%$. Wattle timber, however, takes longer to grow than eucalyptus and is more expensive than eucalyptus timber.

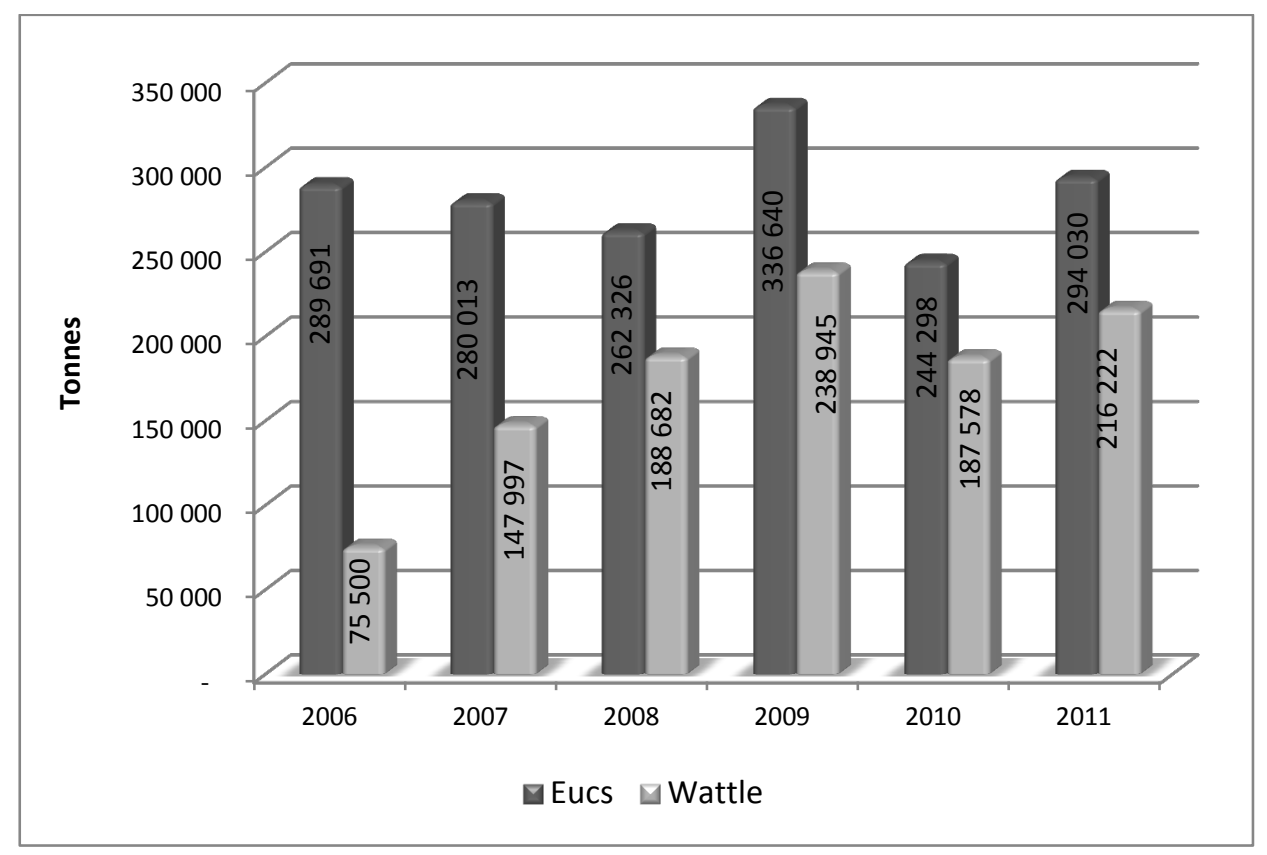

FIGURE 1: Annual wood chip exports from Durban per specie, 2006 to 2011

Source: Authors compiled from NCT Durban Wood Chips (Pty) Ltd., (2011)

Wattle wood chips exported in 2010 totalled 1153000 tonnes and gum totalled 1114000 tonnes. The total tonnage exported was 2267000 tonnes on 59 ships. 46 of these ships were from the Port of Richards Bay and 13 from the Port of Durban. As the Japanese hardwood chip market recovered from the high stock levels of wood chips, the supply pattern into the important Japanese market improved and stabilised (Niebuhr, 2011). According to the same source, the 
long-term relationships that have been developed by NCT and its wood chipping subsidiaries and its Japanese customers and trading houses were invaluable in creating financial stability for NCT's members.

Japanese paper companies are the largest purchasers of wood chips from South Africa. Wood chip imports by Japanese companies for the year 2010 amounted to a total of 28.8 shiploads of wattle wood chips and 30.2 shiploads of gum wood chips. From the Port of Durban 5.5 shiploads of wattle wood chips and 7.5 shiploads of gum wood chips were purchased totalling 13 shiploads carrying 510000 tonnes. A total of 2267000 ton of wood chips were purchased by eight Japanese paper companies namely Nippon, Moorim, M-real, Daio, Chuetsu, Hokuetsu, Mitsubishi and 0ji.

\subsection{Challenges faced by private timber farmers}

The private timber farmers in the forestry sector are facing a number of challenges that prevent them from increasing timber production. The most significant challenges include land reform, fires, transportation costs, timber theft and municipal rates.

\subsubsection{Land Reform and Land Claims}

The Restitution of Land Rights Act 22 of 1994 (South Africa's land reform programme), adopted in 1994 by the African National Congress (ANC) led government, has a long way to go in redressing the historical injustice of land dispossession, forced removals and denial of access to land (Seokoma, 2011). The target set by the land reform programme was a 2014 deadline for a third of the country's farmland to be redistributed from white-owned farms to the black majority. Seokoma (2011) is of the view that The Restitution of Land Rights Act of 1994 allows South Africans to claim back their land, which was lost as a result of the Land Act of 1913. According to Seokoma (2011) by 2004, a total of 36489 claims had already been settled involving about 85000 households.

When apartheid was dismantled, less than $10 \%$ of the population was made up of whites who owned $90 \%$ of the land. Seokoma (2011) states that black people need their ancestral land and aim to utilise this land for agricultural production [subsistence or commercial], for settlement or for non-agricultural enterprises. Seokoma (2011) is of the view that without land, it will be impossible for them to participate in the mainstream economy. The South African government has already indicated its intention to review both the Land Restitution Act of 1994 and the principle of 'willing buyer and willing seller'. Like many South Africans, policymakers included, Gugile Nkwinti (Rural Development and Land Reform Minister in 2010) shares the sentiment that this principle has not worked. Seokoma (2011:3) states that:

\footnotetext{
the problem with this principle is that landowners are not obliged to sell their land, even if communities have sufficient proof that it belongs to them. In addition, this principle has created room for landowners to charge exorbitant prices, especially when selling the land to government for redistribution.
}

According to Lahiff (2008), after 14 years of democracy in South Africa, the political and social spectrum has agreed that the land reform programme is in severe difficulties. The criticism of the land reform programme is that it is failing to reach its targets or to deliver on its multiple objectives of historical redress, redistribution of wealth and opportunities, and economic growth. The particular weaknesses highlighted include the failure to have a significant impact on the land tenure systems prevailing on commercial farms and in the communal areas, the slow pace of land redistribution, and the widespread perception that what redistribution of land has 
taken place has not been translated into improvements in agricultural productivity or livelihood benefits for the majority of participants (Lahiff, 2008).

According to Joemat-Pettersson (20093), land claims from local communities are putting pressure on the forestry industry. About $65 \%$ of privately owned plantations are under land claims and this will have an impact on the sector, especially in terms of securing the resource for future operations. Therefore, Mondi, for example, has dedicated departments for dealing with land claims and for educating and supporting the new owners on forestry.

\subsubsection{Fires}

According to Godsmark (2007), 2007 was a year with many fires in South Africa. During the period between the end of June and early August, approximately 77000 of the 1.2 million hectares of plantations were damaged by runaway fires. This damage occurred mainly in KwaZulu-Natal (KZN). This damage represented $6.4 \%$ of the national plantation resources. These fires had a severe impact on the environment and on biodiversity. Visits to the burnt-out areas in the affected region revealed that the topsoil was left exposed to the elements and that there were no signs of life. Godsmark (2007) also reported that the fires caused damage estimated at approximately R2 billion, and another R6 billion to downstream processing. During 2009, 19805 ha of timber was destroyed by fire (Godsmark, 2010).

\subsubsection{Transportation costs: road and rail}

Transport costs may significantly impede international trade. In 2009, the tonnage transported by road was $88.7 \%$ and $11.3 \%$ by rail (King \& Ittmann, 2011). King and Ittmann (2011) are of the view that too much freight is being transported by road. While market forces determine these matters, one should nevertheless ask the question whether or not rail is cheaper than road transport. In order to have economic growth and development, modern and well-maintained infrastructure is critically important. Supply chains using trucks drive on and are the major users of our extensive road infrastructure network. South Africa has a wide-ranging road network that goes through the entire country but millions of rand in damages is caused each year to vehicles by potholes, which are caused mainly by heavy-duty vehicles.

Only profitable rail infrastructure is utilised by the rail services, while large stretches - notably the branch lines - in the more rural areas are not used and are becoming increasingly dilapidated (King \& Ittmann, 2011). Over the past six years, the growth of freight on rural roads and rail has increased by $85 \%$ and the infrastructure on which this freight is carried is deteriorating at an alarming rate (King \& Ittmann, 2011). Steyn and Bean (2011) show that company logistics costs have increased considerably as a result of the increase in maintenance and repair costs caused by the deteriorating road quality. Cargo on motorised trucks is damaged as these vehicles that travel on the deteriorated roads experience increased vibrations. The other consequences of trucks travelling on damaged roads are increased fuel consumption and increased road damage and damage to the environment (Steyn \& Bean, 2011).

FIGURE 2 illustrates the decline in the volume of cargo transported by rail and the increase in the volume of cargo transported by road transport as estimated by NCT Forestry. The tonnage transported by rail has decreased by $63.76 \%$ between the years 2000 and 2011 while road transport has increased by $125.83 \%$ over the same period. According to Mac (2010), the decline of freight rail over the past few years has been fuelled by high rail tariff increases, poor service, 
collapsing infrastructure and the closure of some branch lines. The combined effect of this scenario is that substantially more timber is being transported by road.

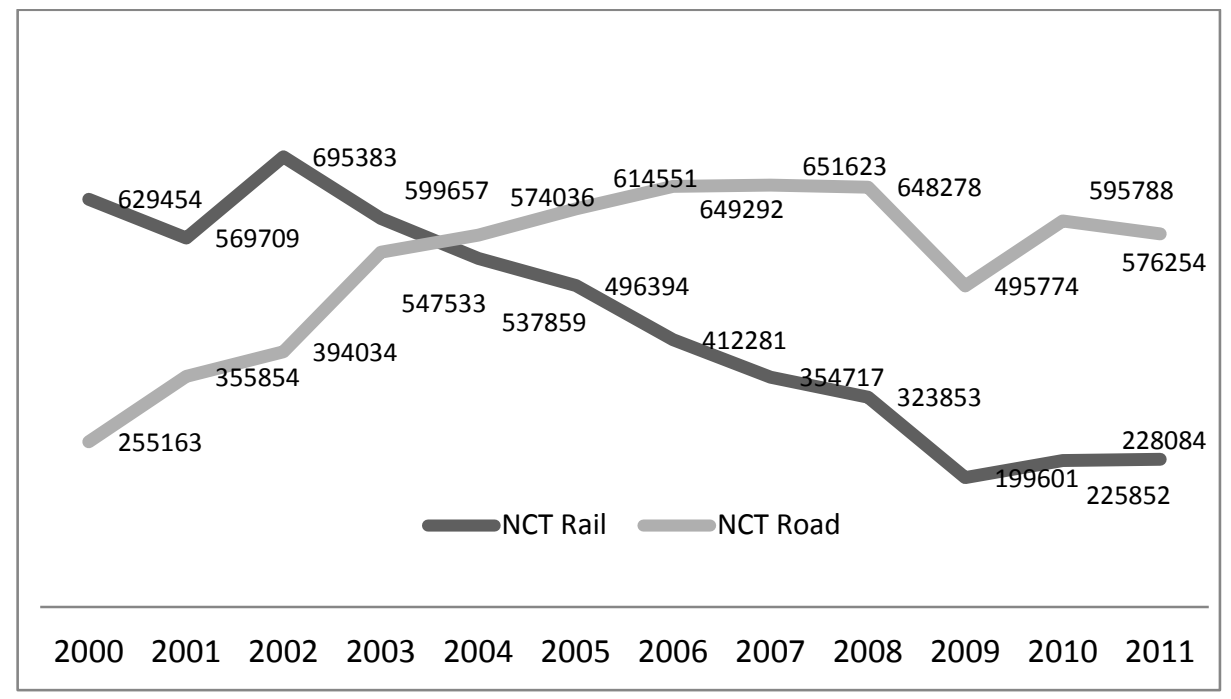

FIGURE 2: Timber transported on rail and road, annual tonnage, 2000 to 2011

Source: NCTForestry Co-operative Limited (2011)

\subsubsection{Municipal rates}

According to Peter (2011), an application was made to the Minister of Provincial and Local Government (subsequently renamed Cooperative Governance and Traditional Affairs) to limit levies by municipalities to the maximum rand rate of $0.5 \%$ for agricultural and forestry property. According to Forestry South Africa's (FSA) Annual Report (2010), FSA has been involved in actions to stop municipalities from charging property rates on agricultural and forestry land that would harm the financial viability of these sectors. Due to this application being denied by the Minister, FSA decided to continue with a legal challenge. Forestry South Africa is of the view that the minister had made an incorrect decision by disregarding the abundant evidence that was submitted, outlining the severe consequences that unsustainably high property rates could cause to the forestry sector. The hearing was held on the 15 April 2011. It was reported that the application was dismissed (Godsmark, 2011). According to Godsmark (2011), regardless of this setback, excellent progress has been achieved concerning the prevention of the possible damage that unsustainably high rates could cause the forestry sector. Municipalities are now starting to proceed more conscientiously and the regulatory environment has changed for the better.

\section{RESEARCH METHODOLOGY AND DATA COLLECTION}

The methodology used in this study included questionnaires and semi-structured interviews that were held with the respondents involved in the forestry industry. A questionnaire was sent electronically to the 119 participants who make up the total population of timber farmers that supply NCT Durban Wood Chips. All these timber farmers were members of the NCT Forestry Co- 
operative Limited. The questions were designed to gather information that would contribute to achieving the objectives of the study.

The management of NCT was approached to acquire the necessary permission to distribute the questionnaire to the participants. The gate-keeper's letter was furnished by NCT management as well as the contact details of the relevant participants from the NCT database. To protect the respondents' confidentiality, the questionnaire was distributed electronically. A covering letter and a link to the electronic survey were sent to the total population of respondents (119). The questionnaires were administered via QuestionPro, an online analytic tool designed for research purposes, which allows for the construction of questionnaires that can be sent online to the relevant respondents. QuestionPro also allows for data analysis and offers various methods of analysing data. The questionnaires were administered between 5 and 23 September 2011. This survey was viewed by 86 people but 41 participants decided not to partake in the survey. A total of 44 participants started the survey and 11 of these participants did not complete the survey. Respondents were informed that they might opt out of the survey if they felt that they no longer wanted to participate. This resulted in 33 surveys being completed representing a response rate of $27.73 \%$. The questionnaire consisted of a total of nine questions. The majority of these questions were closed-ended but some were open-ended to allow further feedback from the respondents. A 5-point Likert scale was used for most closed-ended questions and other questions prompted numerical responses. Descriptive statistics were used to analyse the responses.

Three key personnel, with a strong forestry background, belonging to NCT Forestry Co-operative Limited were selected as participants for the qualitative aspect of the study. These respondents included the group general manager, the group logistics manager and the group assistant general manager. An interview schedule was drawn up consisting of eight open-ended questions. These key personnel were selected on the basis that they had a strong forestry background and were involved on a daily basis with timber farmers for the supply of timber to the NCT Forestry group of companies.

This study did have limitations. Due to confidentiality of members' details, the questionnaire had to be forwarded to the respondents electronically via NCT Forestry Co-operative Limited. This is a limitation in that there was no direct contact (face-to-face) with the respondents and this could have contributed to the low participation rate. Furthermore, as 33 respondents out of 119 completed the questionnaire, the findings cannot be generalised. Nevertheless the findings are useful and informative and supported by the reviewed literature.

\section{Findings and discussion}

\subsection{Timber availability / shortage}

The results showed that $48 \%$ of respondents had eucalyptus (gum) plantations and $44 \%$ had wattle while $8 \%$ had pine plantations. Wood chip mills export wattle and gum wood chips only to the international pulp and paper mills. Wattle, being a much harder species, takes longer to grow and has better yields than gum. Wattle trees are harvested in 8- to 12-year cycles. Gum trees grow faster and are harvested in 6- to 11 -year cycles. Wattle, being a denser species, fetches a higher price than gum for the farmer and the chip mill. Pine plantations account for $8 \%$ of the respondents. Pine trees take longer to grow and are harvested between 25 and 30 years, and are used predominantly in the furniture industry (Pogue, 2008). This is one of the key reasons why 
pine seems to be less of a plantation priority for the larger timber farms. The data supports the point made by Arnold (1998) that a significant share of the planted area is accounted for by small farmers.

Respondents were asked to indicate their potential timber production tonnage forecast for the next five years. Analysis of the 33 farmers' forecasts gathered through the questionnaire showed that between the years 2011 to 2015 the tonnage for gum has a steady predicted increase yearon-year and that the percentage of gum available will increase by $19.7 \%$. The forecast for the 2011 year is 170600 tonnes while the forecast for the 2015 year is 204200 tonnes. This growth shows that the plantation stock of gum is increasing year-on-year. The tonnage for wattle also had a steady increase year-on-year. Between 2011 and 2015, the percentage of wattle available will have increased by $10.9 \%$. The forecast for the 2011 year is 136500 tonnes while the forecast for the 2015 year reflects 151424 tonnes. This growth shows that the plantation stock of wattle is increasing. The pine tonnage, however, seemed to be stagnant. Pine production was on average 9000 tonne per annum. It could be that the demand for wattle and gum chips is increasing and that pine farmers are converting their plantations to gum and wattle plantations. It could also be due to the long period that pine plantations take to grow. Sappi Saiccor and Mondi Merebank have closed their pine pulp lines. This is also why there is no growth in the pine plantations and why the wattle and eucalyptus plantations are expanding. This increase in the plantation stock will make a significant contribution towards economic growth by the processing of these trees for the export market as confirmed by the Department of Agriculture, Forestry and Fisheries (2009). The results confirm that the supply of wattle and gum is definitely forecast to grow until 2015.

Respondents were asked to indicate how many more years they envisage their farms continuing to produce timber. The aim of this question was to understand the longevity of timber farms. The data gathered indicates that $27 \%$ of the farms will continue producing gum for between 31 and 60 years while $29 \%$ of the total number of farms producing wattle will continue producing timber for between 31 and 60 years and the total number of farms that will continue producing pine for between 0 and 30 years will be $2 \%$. Only $2 \%$ of farms will continue producing pine, wattle and gum timber for longer than 120 years.

The responses to the question on how many years the respondents could envisage the production of timber at their farms were concerning. This was a very critical question as the study partly revolved around the supply of pulpwood for now and for the future. The results showed that $27 \%$ of respondents will continue to produce gum for between 31 to 60 years while $29 \%$ of respondents will continue to produce wattle. This may be a cause for concern as the number of forecast years appears to be limited to 60 years.

With regard to the factors within their control, farmers need to be given incentives to continue farming. One of the incentives could be the reduction in or even exemption of productive farms from municipal rates. According to Forestry South Africa's Rodger Godsmark (2010), the land used for forestry has declined. Forestry areas were reduced by 127000 hectares between 1999 and 2009. This represented a $9.1 \%$ decrease in forested area. In South Africa, land available is 122.3 million hectares. However, forestry only uses $1 \%$ of this land. $68.60 \%$ of the land is used for grazing purposes (Godsmark, 2010). In KwaZulu-Natal the land area is 9.10 million hectares, which is $7.5 \%$ of the total land area of South Africa. Forestry utilises $5.5 \%$ of the land in KwaZulu-Natal while grazing utilises $58.30 \%$ (Godsmark, 2010). If more land could be converted from grazing to forestry the availability of timber will increase. This may create more jobs and ultimately the economy will benefit. 


\subsection{Dominant reasons for the decline in timber production}

The respondents were asked what they would describe as the dominant reasons for the decline in timber production and to rank these according to a 5-point Likert Scale. The factors, in total, included, land claims, crop change, timber theft, fire and transportation costs. All of the factors were acknowledged by the respondents, The most dominant factors are discussed below, as these factors attracted the most response from the participants.

\subsubsection{Land reform}

Land reform does not affect all farmers in Southern KwaZulu-Natal. The area that was affected was the Eston Area. The majority (70\%) of the respondents considered this to be the most critically important reason for the decline in timber production. There was uncertainty concerning land reform. Because of the uncertainty, the farmer tends to neglect the affected areas, which results in lower yields. If the farmer was under the impression that his/her farm was going to be affected by land reform, then the farmer may harvest the existing timber and does not have a great incentive to replant the areas harvested. Land reform takes a long time to be settled and could run into years. During that period the farm is unproductive. According to Lahiff (2008), the land reform programme is in difficulty and has failed to reach its targets. Productive farms that have been redistributed have become unproductive. This could be because of the lack of skill or motivation by the recipients. The potential impact of land claims (and redistribution) on the forestry industry and the effect that this may have on the forest products industry could be detrimental. It is in everybody's interest that the restitution process be completed as quickly as possible and in a manner that is fair, transparent and does little damage to the future sustainability of forestry.

\subsubsection{Transportation costs: road, rail and ports}

The results showed that $42 \%$ of the respondents considered transportation costs to be very important and $55 \%$ as critically important. All respondents ranked transportation costs as important to some degree. As pointed out above, rail transport has become more expensive and the demise of the branch lines has necessitated the increased use of road transport. As mentioned by King (2011), only profitable rail infrastructure is utilised while the branch lines in the rural areas are not used and are becoming dilapidated. Due to the demise of the rail network, there has been an increase in road transport. The questionnaire results for road infrastructure showed that $64 \%$ of the sample considered road challenging. The overall importance rating was $97 \%$ collectively. There have been high truck volumes travelling on rural roads, which damage the road infrastructure. This has increased company logistics costs through the increase in maintenance and repair costs caused by the deteriorating road quality (Steyn \& Bean, 2011).

TABLE 1 shows the road and rail tariff increases for the years 2000 to 2011 . The migration of timber from rail to road over the past five years is a symptom of rising freight tariffs, the closure of branch lines and poor rail service. The consequences for timber growers and processors are increasing transport costs and the marginalisation of timber growing areas situated far from the mills (Mac, 2010). 
Naidoo \& Chasomeris

TABLE 1: Percentage change in South Africa's road and rail costs, 2000 to 2011

\begin{tabular}{lcccccccccccc}
\hline & 2000 & 2001 & 2002 & 2003 & 2004 & 2005 & 2006 & 2007 & 2008 & 2009 & 2010 & 2011 \\
\hline Rail & 5 & 3 & 15 & 15 & 20 & 5 & 4 & 7 & 22 & 18 & 12 & 5.5 \\
Road & 3 & 4 & 8 & 6 & 3 & 7 & 5 & 6 & 10 & 9 & 7 & 7 \\
$\begin{array}{l}\text { CPIX } \\
\text { to } \\
\text { CPI }\end{array}$ & 7.7 & 6.6 & 9.3 & 6.8 & 4.3 & 3.9 & 4.6 & 6.5 & 11.3 & $7.1^{1}$ & 4.3 & 5 \\
\hline
\end{tabular}

Source: Authors compiled, using data from NCT Forestry Co-operative Limited (2011) and Statistics South Africa (2012)

Note: South Africa changed from using CPIX to using CPI in 2009

According to Goately (2009), the main contributor to South Africa's deteriorating road infrastructure is over-loading. The Road Transport Management System (RTMS) is an industryled self-regulation scheme that encourages users engaged in road logistics to act responsibly. Its purpose is to implement a vehicle management system that preserves road infrastructure, improves road safety and increases the productivity of the logistics value chain. The prospect of improving efficiencies and reducing costs in round log timber supply chains is invaluable as the timber industry transports approximately 14 million tonnes per annum (Goately, 2009). Van Zyl (2010) is also of the view that over-loading causes accelerated road deterioration that, together with inadequate vehicle maintenance, driver fatigue and poor driver health, contributes significantly to South Africa's poor road safety record.

In March 2010 the price of diesel was R6.90 per litre in the coastal areas and in March 2011 the price was R8.64 per litre. The increase equates to $25 \%$ year-on-year. The timber farmer's overall cost, including transport and harvesting, increased by $53 \%$ as a result of the increase in the diesel fuel price (Goately \& Van Zyl, 2011). Increased costs reduce the timber farmer's profit margins.

TABLE 2 illustrates the tariff paid annually for the export of wood chips from the Port of Durban. The average annual increase between 2007 and 2011 was 5.92\%. The proposed increase for the financial year ending April 2012 was $612.37 \%$.

TABLE 2: Port tariffs for wood chips over the past seven years

\begin{tabular}{cccccr}
\hline YEAR & $\begin{array}{c}\text { Tariff } \\
\text { (ZAR) }\end{array}$ & $\begin{array}{c}\% \\
\text { Increase }\end{array}$ & yEAR & $\begin{array}{c}\text { Tariff } \\
(\text { ZAR) }\end{array}$ & $\begin{array}{c}\% \\
\text { Increase }\end{array}$ \\
\hline $2006 / 2007$ & 4.56 & - & $2011 / 2012$ (Proposed) & 40.89 & $612.37 \%$ \\
$2007 / 2008$ & 4.77 & $4.60 \%$ & $2011 / 2012$ (Actual) & 6.00 & $4.53 \%$ \\
$2008 / 2009$ & 5.09 & $6.71 \%$ & $2012 / 2013$ (Proposed) & 7.08 & $18.06 \%$ \\
$2009 / 2010$ & 5.50 & $8.01 \%$ & $2012 / 2013$ (Actual) & 6.17 & $2.76 \%$ \\
$2010 / 2011$ & 5.74 & $4.36 \%$ & & & \\
\hline
\end{tabular}

Source: $\quad$ Authors complied from Reitz (2010) and Transnet National Ports Authority (2012) 
According to Reitz (2010), if the proposed tariff increase for wood chips is approved, the resultant effect will be a loss of profits in excess of R50 million to the members of NCT Forestry Co-operative Limited. More than $25 \%$ of NCT Forestry's 2000 members are small black growers who farm on tribal land in Zululand and the KwaZulu-Natal midlands. A significant quantity of wood chips also comes from farms that have become owned by black communities as a result of the government's land restitution programme. Wood chips are sold in US Dollars. The exchange rate of the South African Rand (ZAR) to the United States Dollar (USD) fluctuates a great deal. NCT Forestry, being a co-operative, acts to stabilise the price of wood chips on behalf of its members. NCT Forestry was subsidising its members by approximately R40 per metric ton (mt) and would not be able to further subsidise its members to account for the proposed tariff increase. The proposed tariff increase would increase the cost of exporting woodchips by about $\mathrm{R} 35 / \mathrm{mt}$. The smaller growers may, in all probability, go out of business if an increase of this magnitude came into effect. Medium and larger growers are also vulnerable, along with their workforces and this increased cost would, through a possible reduction in future market demand, create an unprecedented ripple effect not only on their workforce, but also on those industries that support these growers. Under such circumstances, the socio-economic effect of the proposed tariff increase or 're-alignment' is catastrophic and cannot be sustained by many businesses in the wood chip industry (Reitz, 2010).

The proposed tariff increase is not systematic, consistent or on a comparable basis given that the annual tariff increase over the past 5 years was between $4.36 \%$ and $8.01 \%$ as set out in TABLE 2 (Reitz, 2010). According to the same source, the proposed tariff increase is unfair to the extent that it disproportionately affects the wood chip industry relative to other proposed port tariff changes and re-alignments. Transnet National Ports Authority (TNPA) is a State-Owned Enterprise ( $S O E)$, and should operate in the public interest. The tariff increase discriminates against the exporters of wood chips and there is no evidence submitted by the TNPA that such discrimination is in the public interest. Given that this increase will also have a disproportionate and discriminatory effect on NCT Forestry's members, and particularly those from previously disadvantaged groups, such discrimination cannot be in the public interest. A 612.37\% increase does not allow predictability or stability for the wood chip industry and will price the wood chip industry out of the international market and effectively result in the collapse of the South African wood chip industry (Reitz, 2010). The Ports Regulator of South Africa decided that a TNPA tariff increase of $4.49 \%$ would be allowed for 2011/12. However, TABLE 2 shows that an actual increase of $4.53 \%$ for wood chips was charged. In 2012, TNPA applied for an $18.06 \%$ tariff increase and the Ports Regulator of South Africa only allowed a $2.76 \%$ increase.

\subsubsection{Municipal rates}

The results showed that only $9 \%$ of respondents ranked municipal rates as unimportant. Municipal rates affect all farmers. According to Forestry South Africa's Annual Report (2011), the rate applicable to farmland is too high and they have approached the Minister of Provincial and Local Government to have this matter addressed.

\subsection{Factors affecting private timber production in the future}

The respondents also ranked the most challenging factors negatively affecting private timber production into the future. The factors, in total, included labour legislation, municipal rates, security, climate change, economics (cost vs. income), land claims, road infrastructure and 
pests and diseases. All of the factors were acknowledged by the respondents. However, the most challenging factors are listed below, as these factors were ranked as the most significant.

\subsubsection{Land claims}

The results for land claims showed that $78 \%$ of the respondents regarded this as critically challenging and that the overall importance rating was $100 \%$ collectively. As noted in the literature review, in the discussion under land reform, farmers believe that land reform is a stumbling block that affects the production of timber. The uncertainty and the long resolution periods have resulted in farms being neglected. The effects of this neglect will only be felt in a few years when the land is unproductive.

\subsubsection{Municipal rates}

The results for municipal rates showed that only $4 \%$ of respondents ranked municipal rates as unimportant whilst $45 \%$ ranked these as critically challenging. As noted in the literature review on discussion under municipal rates, Forestry South Africa is of the view that the rate applicable to farm land was too high and has approached the Minister of Provincial and Local Government to have this matter addressed.

\subsection{Economics (cost vs. income)}

All of the respondents ranked economics (cost vs. income) as challenging to some degree, with $47 \%$ of the population considering this to be very challenging and $38 \%$ as critically challenging. Cash flow is an important factor for the survival of the farmer as timber farming is capital intensive. Due to the long rotation periods of timber, the farmers have long waiting periods before income is earned. Contractors were used by timber farmers to do the planting, harvesting and transporting. Farmers generally do not have their own transport as it is capital intensive and not cost effective and, therefore, it is cheaper to use contract transporters. Timber harvesting is also very labour intensive as it involves many people in all aspects of the operation. The benefit of timber farming is that the crops can be harvested at any stage. If the timber price is low the timber can be left until the price has increased. There is also no specific season that farmers need to harvest, one can harvest on demand. Fire is a major threat to farming, therefore, large sums of money need to be spent on fire-fighting equipment and firebreaks have to be burnt every year at the beginning of winter to prevent huge fires from destroying the crops.

\subsection{Market availability}

The responses to variation in the demand for timber showed that only $7 \%$ ranked demand for timber as not challenging while $45 \%$ of respondents considered market availability as very challenging. Some parts of the country have experienced a shortage of timber as mentioned in the Forestry Roadmap 2030 (2009). This shortage will have an unfavourable effect on the sustainability of pulp and paper operations, local sawmilling and, therefore, poses a threat to employment opportunities and to the local economy. Fewer hectares have been replanted and the effects of this will be felt in a few years (Thompson, 2008). The export of wood chips has been increasing from Durban. During and Whales (2009) are also of the view that the export market for pulp and paper is strong. With the reduction of the land area available for timber plantations there will always be a demand for wood chips. 


\subsection{The future supply of wood chips}

The three interviewees were asked to outline and describe significant changes in pulpwood supplies from suppliers in Southern KZN on an annual basis. The logistics manager indicated that, while there was not a significant change to pulpwood supplies, the most critical aspect was that markets continued to recover from recent global difficulties. This, to a limited extent, was improving the volumes harvested on farms. The general manager and assistant general manager indicated that Bainesfield farm will start maturing. Bainesfield is a farm that was leased by NCT Forestry. Between 1999 and 2014, 3400 hectares of pulp wood timber would have been planted. Smithii and Grandis (both being gum species) have been supplied to the Durban Wood Chip mill from this plantation in the past and this holds a future benefit for the Durban mill. With an improvement in pulp yields and a Mean Ring Index (MRI) of 15, this farm will produce approximately 50000 tonnes. With an MRI of 18 the plantation will produce approximately 60 000 tonnes. The assistant general manager stated that the most robust and stable supply of timber was from NCT Tree Farming. This was more reliable and beneficial to the Durban Wood Chip mill than other sources. The general manager mentioned that small steps have been taken to ensure the stability of timber supply through the joint venture partnership with Freewheel. Freewheel is a partnership between the Japanese client Hokuetsu Kishu Paper and NCT Forestry Co-operative. The general manager and assistant general manager explained that Freewheel had purchased a farm called Etterby and purchased two more farms in the Greytown area. The timber produced from these farms will go to the Durban Wood Chip mill.

It can be seen from this that NCT Forestry is taking the necessary steps to improve the availability of timber by investing in farms through partnerships, leases and through NCT Tree Farming. Better maintenance and species selection were efforts that have been made to improve yields on these farms. Furthermore, all the timber from the new acquisitions was destined for the Durban Wood Chip mill. This shows that the availability of timber can be improved to meet export demand.

\subsection{Interviewees perspectives on the challenges and motivations to produce pulpwood in Southern KwaZulu-Natal}

The interviewees were also asked to give their views on the most challenging issues that the private South African timber grower had to deal with. The logistics manager indicated that the availability of productive labour and the impact of urbanisation plus the impact of HIV and AIDS on rural communities in conjunction with land claims were the major challenges.

The general manager mentioned that transport costs have increased a great deal compared with five years ago. A positive for the Durban Wood Chip (DWC) mill is its proximity to Durban. Due to Richards Bay being a long distance away from Durban, it became too expensive to transport the timber from Durban to Richards Bay. Previously farmers from the Richmond area could send their timber by rail to Richards Bay. These rail lines to Richmond are now closed and the other alternative was to use road transport. Timber now has to be road hauled from places that only used rail transport in the past. The general manager stated that transport cost was the most prominent issue that the timber farmer has to face. The general manager mentioned that the issue of land claims is of general concern but that it actually only affects a few farmers. The land claims affected some farmers in the Eston area. The general manager did mention that he felt that the land claims issue is not as big a concern as it is made out to be. The assistant general manager mentioned that farmers did not manage their farms as they used to 10 to 15 
years ago because of the fear that their land was going to be taken away as part of the land claims. NCT was playing a role in trying to change this mind-set among farmers. The general manager said that property rates and paying for water levies was another challenging issue that the farmers had to deal with. The general manager did mention that property rates were a wasteful expenditure for farmers as they paid for it every year and it increased every year and they did not see any benefit from it.

The increased transport cost was a variable over which the farmers had little control. The option of using rail was no longer available due to the fact the rail lines had been closed. The rail network had not been maintained resulting in timber farmers using road transport. The excess use of road transport, as has been mentioned, meant that the road network gets damaged and becomes more expensive to maintain. The factors mentioned by the general manager and assistant general manager - transport costs, municipal rates and land claims - are the most challenging factors that the farmers have to deal with. The 33 respondents that answered the questionnaire also rated these factors as important overall.

The three interviewees were asked: What in your opinion are the key threats that influence the production of pulpwood in Southern KZN? The logistics manager responded that the reallocation of land (land claims) without skills transfer and the availability of farm labour was a key threat to pulpwood production. The general manager and assistant general manager responded that the land issue was a threat to pulpwood production in the North. Communities took over farms and within two years there was nothing on those farms due to the communities not replanting. This has happened in the South but has not affected the supply of pulpwood from Southern KZN. If a farm was going to be a casualty of the land claims, one would find that there was an increase in the flow of timber from that farm in the short term but the impact was felt later as no further tree planting and management would take place on that farm.

Community development could be another threat. For example, plantation land could be converted to low-cost housing or conversion to other land uses. Southern KZN is pulpwood terrain, which supports Sappi Saiccor, Mondi Merebank and Durban Wood Chips. Other threats could be pests and diseases. Tree breeders and geneticists are constantly researching ways to combat and eradicate pests and diseases. Fire was always a threat but through good management this threat can be minimised. The effects of global warming on timber farming needs to be further studied. The strong Rand also affected the export of wood chips. If the Rand was too strong then it would not be cost effective to export wood chips. Biofuels was a further potential threat for pulpwood production but not in Southern KZN. Land claims, community development, pests and diseases and fires were considered to be key threats.

The interviewees were asked to give their views on the driving factors that kept timber farmers in the business despite the challenges they face daily. The logistics manager responded that it is the quality of life and that for many farmers the business was in the family. The general manager and the assistant general manager responded that there were always farmers who were consolidating their farms and who purchased the farms from the farmers who wanted to leave. NCT Tree Farming also managed farms for farmers who wanted to exit. The farmers retained ownership of the farms and the management is done through NCT Tree Farming. The joint venture between Hokuetsu and NCT keeps the timber moving to the Durban mill. Due to the fact that wood chips were sold in US Dollars, the farmer is able to achieve higher rates during the time of Rand weakness. During the period of the strong Rand, as it has been over the last two years, NCT negotiated with the Japanese clients to increase prices and vice versa. NCT has a lucrative market in Japan as NCT supplied $65 \%$ of the total wood chips exported to the Japanese paper 
companies from South Africa. The Japanese client had investments in South Africa and the relationship with the client is long-term. The proposed increase in the port charges of $18 \%$ was excessive but with the intervention of the Port Regulator the proposed increase would be in line with inflation and, therefore, will not affect the timber farmer. The availability of hardwood will increase in Southern KZN with the conversion from soft wood (pine) to hard wood. This was done by Masonite a few years ago. Mondi and Sappi have closed down their pine sections. South of the Tugela there was little or no need for soft wood. The Southern KZN pulpwood land area has gradually diminished but, through good management, the yields were increasing in timber plantations. The increased yield will make up for the shortfall in land. The conversion from softwood to hardwood will also increase the production of pulpwood.

When farmers are exiting there are always farmers who want to consolidate their farms and who purchase these farms. NCT Tree Farming also manages farms on behalf of those who want to exit. The more successful farmers who purchased other farms managed these farms well and, therefore, the yields increased. The Japanese are the largest wood chip buyers in the world and always look at long-term sustainability. The exchange rate variations or volatility was counteracted by the price increase or decrease as agreed with a client. Although the pulpwood land area was diminishing there was an increase in the yield from the plantations through good management and species selection.

\section{CONCLUSION}

The aim of this study was to examine the trends in wood chip exports from the Port of Durban and the challenges faced by private pulpwood farmers in Southern KwaZulu-Natal.

The interviews and questionnaires gathered information on challenges faced by private pulpwood farmers in Southern KZN. The findings of the study showed that wood chips exports have increased from the Durban facility between 2006 and 2011. Wattle and gum wood chips were exported to international pulp and paper mills. Some $48 \%$ of respondents had gum plantations while $44 \%$ had wattle plantations and pine plantations accounted for $8 \%$. The results showed that from 2011 to 2015 the percentage of gum available is forecast to increase by $19.7 \%$ and wattle by $10.9 \%$ while pine will remain stagnant.

Results showed that the dominant reasons for the decline in land under plantations were land reform, transportation costs and municipal rates. Although the land under plantation was deceasing, there was an increase in yields. Land claims, road infrastructure, cash flow and variations in the demand for timber were the most challenging factors affecting private timber production into the future. Farmers have little control over several of these factors. Furthermore, $92 \%$ of timber farmer respondents have not planned to produce timber beyond 60 years. Nevertheless, the qualitative findings and quantitative results confirm that timber production is definitely increasing and hence contributing to stability of private pulpwood production in Southern KwaZulu-Natal. 


\section{LIST OF REFERENCES}

Arnold, M. (1998). Trees as Out-grower Crops for Forest Industries: Experience from the Philippines and South Africa. Network Paper 22a. [Online]. Available:

http://www.odi.org.uk/resources/details.asp?id=755\&title=trees-as-out-grower-crops-forestindustries-experiences-philippines-andsouth-africa. (Accessed 11 April 2011)

Chamberlain, D., Essop, H., Hougaard, C., Malherbe, S. \& Walker, R. (2005). The contribution, costs and development opportunities of the Forestry, Timber, Pulp and Paper industries in South Africa. Johannesburg: Genesis Analytics (Pty) Ltd.

Department of Agriculture Forestry and Fisheries.( 2009). Forestry 2030 Roadmap (Forestry strategy 2009 - 2030). Department of Agriculture Forestry and Fisheries [Online] Available: http://www.daff.gov.za/doaDev/doc/IGDP/Forestry\%202030\%20Roadmap.pdf. (Accessed 24 September 2011)

During, C. \& Whales, C. J. (2009). Economics Forestry and Paper. [Online] Available: http://www.kwazulunatalbusiness.co.za/pls/cms/ti_secout.secout_prov?p_sid=27\&p_site_id=130. (Accessed 26 September 2011)

Forestry South Africa. (2010). Forestry South Africa 2010 Annual Report. [Online] Available: http://www.forestry.co.za/uploads/File/about/annual_reports/fsa_annual_report_2010.pdf. (Accessed 28 September 2011)

Goately, B. (2009). News \& Views : Over-loading a No No. Pietermaritzburg, South Africa: NCT Forestry Co-operative Limited.

Goately, B. \& Van Zyl, J. (2011). News \& Views: Logistics - Impact of Diesel Fuel increase on Timber Growers. Pietermaritzburg South Africa: NCT Forestry Co-operative Limited.

Godsmark, R. (2007). Forestry South Africa: Fire storms rip through KZN, Mpumalanga, Limpopo \& Swaziland. SA Forestry Magazine. Durban: Artworks Communications.

Godsmark, R. (2010). Forestry South Africa: The South African Forestry and Forest Products Industry 2009 [Online] Available:

http://docs.google.com/viewer?a=v\&q=cache:zOCainHJ7iUJ:www.forestry.co.za/uploads/File/home/ facts/SA_Forestry_Industry_2010_colour.ppt+The+South+African+Forestry+and+Forest+Products+In dustry+2009\&hl=en\&gl=za\&pid=bl\&srcid=ADGEESj5AtC_h0ds_IMKyln_hViPX84E5M5DzrWcgsXbFHDmjsO GszYC2EXD0nNjix)E2s3K-8Cy7BE3Dq_WHbyN4UX3cUWY2z0jClyXpTIP9yRmD6g4h71PkRUypWY6qLH3ncy5aYp\&sig=AHIEtbSTd_bBT291EztvKROle2Y5N 8Pqdg. (Accessed 15 February 2011)

Godsmark, R. (2011). Forestry South Africa: Kwanalu property rates court case update. [Online] Available: http://www.saif.org.za/uploads/July\%202011\%20SAIF\%20Newsletter.pdf. (Accessed 22 September 2011)

Joemat-Pettersson, T. (2009). Department of Agriculture Forestry and Fisheries: Forestry 2030 Roadmap (Forestry strategy 2009 - 2030). [Online] Available:

http://www.daff.gov.za/doaDev/doc/IGDP/Forestry\%202030\%20Roadmap.pdf. (Accessed 24 September 2011)

Keyser, V. (2011). News \& Views: Three Million Tonne Milestone. Pietermaritzburg South Africa: NCT Forestry Co-operative Limited.

Kime, P. (2009). News \& Views : From the General Manager. NCT Forestry Co-operative Limited, Pietermaritzburg, South Africa: NCT Forestry Co-operative Limited. 
Kime, P. (2010). NCT Forestry Co-operative Limited Annual Report Twenty Ten: General Manager's Report. Pietermaritzburg, South Africa: NCT Forestry Co-operative Limited.

King, D. (2011). $7^{\text {th }}$ Annual State of Logistics Survey for South Africa 2010 [Online] Available: http://www.csir.co.za/sol/docs/7th_SoL_2010_March.pdf. (Accessed 27 September 2011)

King, D. \& Ittmann, H. W. (2011). 7th Annual State of Logistics Survey for South Africa 2010. CSIR, Pretoria, South Africa. [Online] Available:

http://www.csir.co.za/sol/docs/7th_SoL_2010_March.pdf. (Accessed 27 September 2011)

KwaZulu-Natal Department of Transport. (2008). KwaZulu-Natal Department of Transport Data bank. [Online] Available:

http://www.kzntransport.gov.za/public_trans/freight_databank/kzn/industries/forestry/index_xml .html. (Accessed 20 August 2011)

Lahiff, દ. (2008). Land Reform in South Africa: A Status report. [Online] Available: http://www.plaas.org.za/pubs/rr/PLAAS_RR38_Lahiff.pdf. (Accessed 06 September 2011)

Mac, R. (2010). Transport and Logistics: Freight Rail: where to from here? SA Forestry Magazine. Durban: Artworks Communications.

National Ports Authority. (2008). National Ports Authority export statistics. [Online] Available: http://www.kzntransport.gov.za/public_trans/freight_databank/kzn/industries/forestry/index_xml .html. (Accessed 20 August 2011)

NCT Durban Wood Chips (Pty) Ltd. (2011). Annual Sales Volume 2011. NCT Durban Wood Chips (Pty) Ltd. Board presentation.

NCT Forestry Co-operative Limited. (2011). Presentation Annual Volumes FSA-TFR. South Africa: NCT Forestry Co-operative Limited.

Niebuhr, H. (2011). NCT Forestry Co-Operative Limited Annual Report 2011: Chairman's Statement. Pietermaritzburg, South Africa: NCT Forestry Co-Operative Limited.

Peter, M. (2011). Forestry South Africa 2010 Annual Report. [Online] Available:

http://www.forestry.co.za/uploads/File/about/annual_reports/fsa_annual_report_2010.pdf. (Accessed 28 September 2011)

Pogue, T. E. (2008). A Sectorial analysis of Wood, Paper, Pulp Industries in South Africa. [Online] Available: http://www.labour.gov.za/downloads/documents/researchdocuments/Wood,\%20paper,\%20pulpsa.pdf. (Accessed 22 September 2011)

Reitz, D. (2010). Written Submissions to the Ports Regulator in Response to the Invitation to comment on the National Ports Authority Tariff Application 2011 / 2012. Durban.

Seokoma, B. (2011). Land Redistribution: A Case for Land Reform in South Africa. [Online] Available: http://www.ngopulse.org/category/tags/land-redistribution. (Accessed 22 September 2011)

Statistics South Africa. (2012).Consumer Price Index: Index numbers and year-on-year rates. [Online] Available: http://www.statssa.gov.za/keyindicators/CPI/CPIHistory.pdf. (Accessed 4 August 2012)

Steyn, W., \& Bean, W. I. (2011). The Potential Effects of Deteriorating Road Quality and Maintenance in South Africa: 7th Annual State of Logistics Survey. CSIR, Pretoria, South Africa. [Online] Available: http://www.csir.co.za/sol/docs/7th_SoL_2010_March.pdf. (Accessed 27 September 2011) 
Taylor, J. (2009). A sustainable population strategy for Australia. Department of Sustainability, Environment, Water, Population and Communities, Australia. [Online] Available:

http://www.environment.gov.au/sustainability/population/publications/issues-paper2.html. (Accessed 10 September 2011)

The Restitution of Land Rights Act 22 of 1994. Pretoria, South Africa. [Online]. Available: http://www.info.gov.za/acts/1994/a22-94.pdf. (Accessed 25 July 2011)

Timberwatch. (2009). Thousands call for a halt to the expansion of monoculture tree plantations. South Africa. [Online] Available:

http://www.timberwatch.org.za/old_site/20090921International_Day_against_Monoculture_Tree_P lantations.pdf. (Accessed 10 August 2011)

Thompson, R. (2008). News \& Views: The Value of Farming. Pietermaritzburg South Africa: NCT Forestry Co-operative Limited.

Transnet National Ports Authority. (2012). Port Tariffs, $12^{\text {th }}$ Edition, 1 April 2012. [Online] Available: http://www.transnetnationalportsauthority.net/DoingBusinesswithUs/Port\%20Tariffs/2012/April/19 .03.12\%20Transnet\%20A5\%20Tariff.pdf. (Accessed 4 August 2012)

Van Zyl, J. (2010). News \& Views: Over-loading. Pietermaritzburg South Africa: NCT Forestry Cooperative Limited. 